\title{
Executive Functions in Adolescents With Idiopathic Generalized Epilepsy
}

\author{
Giedrè Gelžiniené ${ }^{1}$, Giedrè Jurkevičiené ${ }^{1}$, Vitalija Marmiené $\dot{e}^{2}$, \\ Virginija Adomaitiené ${ }^{2}$, Milda Endziniené $\dot{e}^{1}$ \\ ${ }^{1}$ Department of Neurology, Medical Academy, Lithuanian University of Health Sciences, \\ ${ }^{2}$ Department of Psychiatry, Medical Academy, Lithuanian University of Health Sciences, Lithuania
}

\begin{abstract}
Key words: idiopathic generalized epilepsy; executive functions; myoclonias; generalized tonicclonic seizures.

Summary. Disorders of executive functioning have recently been reported in patients with juvenile myoclonic epilepsy (JME); however, data on other syndromes of generalized idiopathic epilepsy (IGE) other than JME, especially in adolescence, are scarce.

The aim of this study was to explore specific executive functions in a group of adolescents with IGE of short duration and to evaluate the possible factors that might influence these functions.

Material and Methods. Neuropsychological investigation of executive functions (the Verbal Fluency Test, the Five-Point Test, the Trail-Making Test, and the Stroop test) was performed in 59 patients aged 14-17 years and meeting the diagnostic criteria for IGE, and in the group of 59 agematched controls without any history of epilepsy.

Results. The IGE group subjects scored worse than the controls in most of the executive function tests: phonemic $(P=0.008)$ and semantic $(P=0.001)$ word fluency, figural fluency $(P=0.008)$, visual search and sequencing of numbers $(P=0.001)$, and alternate number-letter sequencing $(P=0.018)$. None of the test scores differed between the new-onset and the established IGE groups, or between the groups of cases with and without myoclonias. No relationship between executive functioning and gender, age, duration or activity of epilepsy, treatment, or epileptiform discharges on electroencephalography was found.

Conclusions. Executive dysfunction was present in adolescents with JME and other syndromes of IGE, manifesting with generalized tonic-clonic seizures without myoclonias, despite short duration and benign course of epilepsy.
\end{abstract}

\section{Introduction}

Idiopathic generalized epilepsies (IGEs) of adolescence comprise a group of age-related epilepsy syndromes characterized by generalized seizures that have a genetic origin and no detectable brain lesion $(1,2)$. IGE is considered a benign condition; patients usually have normal intellectual abilities, and their seizures are well controlled with antiepileptic drugs. Yet, the studies that evaluated intellectual abilities of patients with IGE have shown a tendency to lower IQ than in general population (3-5). The impairment of various cognitive functions such as attention, memory, and executive functions in patients with IGE has been reported $(4,6-8)$. The impairment of certain cognitive functions is very important in school-aged patients since it may influence their learning process and lead to psychosocial and professional impact even for children with normal intelligence and well-controlled seizures (4, 9). Idiopathic epilepsies without structural brain changes constitute a better model for evaluating the impact of disease-related characteristics and paroxysmal epileptic activity on cognitive functions than

Correspondence to G. Gelžinienė, Department of Neurology, Medical Academy, Lithuanian University of Health Sciences, Eiveniu 2, 50028 Kaunas, Lithuania

E-mail: giedregelziniene@hotmail.com symptomatic epilepsies (10), and therefore investigations of various aspects of cognition in idiopathic epilepsies are in process. Recently, executive functions, mainly associated with the function of the frontal cortex, have gained much attention and have been studied in patients with epilepsy, particularly in case of juvenile myoclonic epilepsy (JME) (1114). Executive functions are a complex set of processes, thought to be responsible for the ability to plan and form abstract concepts and goals, adjust to changing demands and new instructions, control attention, impulsivity, and emotions $(15,16)$, and thus are very important in everyday life and learning process. Data from studies involving patients with JME show a range of deficits in various executive functions $(6,11-13)$ suggesting the impairment of frontal and prefrontal regions. Neuroimaging studies revealing subtle structural abnormalities in the prefrontal region (17-20) suggest a frontal lobe dysfunction in JME and even raise a question if JME is a truly generalized epilepsy syndrome. However, results of the studies are inconsistent, and there is some evidence that slight abnormalities of frontal

Adresas susirašinėti: G. Gelžinienė, LSMU MA Neurologijos klinika, Eiveniu 2, 50028 Kaunas

El. paštas: giedregelziniene@hotmail.com 
lobes in JME should be taken with care of overinterpretation $(14,21)$. It remains unclear if impaired executive functions are common features of IGE, with very few studies addressing this issue and the results being not uniform $(7,9,22)$. Another question is if these impairments are constant or dependent on a reversible transient impact of seizures or interictal discharges (10). In general, there is a lack of studies addressing cognitive domains of adolescent patients with IGE and its syndromes, since some of the studies related to this age group analyzed both partial and generalized idiopathic epilepsies together (8, 22-24).

The aim of this cross-sectional study was to analyze the specific executive functions in a group of adolescents with IGE of short duration and to evaluate the possible seizure-related factors that may influence these functions.

\section{Material and Methods}

Subjects. The study group comprised the patients with idiopathic generalized epilepsy aged 1417 years who were followed up at the tertiary center (Department of Neurology, Hospital of Lithuanian University of Health Sciences Kaunas Klinikos) during 2009-2010. The study was approved by the Regional Bioethics Committee and the State Data Protection Inspectorate, and all the patients and their parents signed their informed consent. Inclusion criteria were as follows: age of 14-17 years; mainstream education and IQ>70 (WISC III, Lithuanian version, neuropsychological evaluation was performed by a licensed clinical psychologist); IGE diagnosis based on clinical and electroencephalography $(\mathrm{EEG})$ criteria $(1,2)$ (the specific EEG characteristics being present either during the study period or any time before) and no clinical or structural brain imaging evidence of organic brain damage; no history of brain trauma with loss of consciousness; no diagnosis of any neurological, psychiatric, or chronic somatic disorders; and no generalized tonic clonic seizures (GTCSs) within the last 24 hours. Patients with absences as the only seizure type were excluded. According to these criteria, 59 adolescents were enrolled. Duration of epilepsy was set as the period from the first unprovoked seizure until the date of the study.

According to the treatment and time of diagnosis, IGE patients were divided into the newly diagnosed and previously untreated IGE group ("newonset") and the group of patients with previously established IGE and treated with antiepileptic drugs ("established"). All patients in the established IGE group were treated properly with sufficient doses of medications.

Because of the difficulties in evaluating seizure frequency in the new-onset epilepsy cases and comparing it to the seizure frequency of patients with established epilepsy, not the seizure frequency but rather the presence of seizure activity within the past 3 months before the study was assessed.

Since myoclonic jerks are considered to be obligatory for the diagnosis of JME (2), the patients were divided into two groups according to the presence $(\mathrm{M}+)$ or absence $(\mathrm{M}-)$ of myoclonic jerks: those with myoclonic jerks were defined as having JME, and patients without myoclonias and with GTCSs as the only seizure type (or in combination with infrequent absences) were defined as having IGE with "GTCSs only." Myoclonias were considered as "active" if patients had myoclonic jerks within the past 3 months occurring at least 3 days per week.

The control group consisted of 59 adolescents matched by age and meeting all the inclusion criteria except of epilepsy at any time of their lives.

Methods. All subjects both of the study and the control group were exposed to four batteries for the evaluation of executive functions: the Verbal Fluency Test, the Five-Point Test, the Trail-Making Test (TMT), and the Stroop Test.

Verbal Fluency. The Verbal Fluency Test evaluates the spontaneous production of words under restricted search conditions. Generation of words that begin with a certain letter (phonemic fluency) or belonging to a certain category by their meaning (semantic fluency) within a limited time is used to assess verbal association fluency and mental retrieval from long-term memory (16). For the analysis of phonemic fluency, the sum of all admissible words for three letters (F, A, and S) was used, and for the semantic fluency analysis, the sum of correct words representing given categories ("Food" and "Animals") was used.

Five-Point Test. This test has been developed as a nonverbal analog to word fluency tasks to measure the production of novel designs under time constraints (16). Patients were asked to produce as many different figures as possible by connecting the dots within presented matrix in 3 minutes. For the analysis, the total number of unique designs and the percentage of repeated designs (perseverations) were used.

Trail-Making Test. The TMT is a measure of speed of attention, sequencing, mental flexibility, visual search, motor function, and working memory (16). The subjects had to connect 25 numbered circles scattered randomly in an ascending order (Part A) and 25 circles with numbers and letters both in an ascending order and in an alternating way (Part B). The time in seconds required for the performance of Part A and Part B was used for the analysis.

Stroop Test. The test is aimed at the evaluation of the ease with which a person can maintain a goal in mind and suppress a habitual response in favor of a less familiar one. It also assesses selective attention, susceptibility to interference, and cognitive flexibility. The Victoria version of this test was used (16). For the analysis, the difference between the execution time of the third ("words") and the first ("colors") 
tasks in seconds and the number of errors/autocorrections during the third task were evaluated.

The results of the tests were initially compared between the IGE group and the control group. Later, comparisons of the control group and the subgroups of IGE according to the duration of epilepsy (new-onset and established IGE) and to epilepsy syndrome (JME and IGE with GTCSs only) were performed, followed by the comparisons of the test results according to the demographic and clinical characteristics within the IGE group.

Statistical Analysis. Data were statistically analyzed by using the SPSS 15.0 for Windows statistical software (SPSS Inc., Chicago, IL, USA). Parameters were evaluated using the Kolmogorov-Smirnov test for the normality of distribution and the Levene test for homogeneity. Parametric and nonparametric statistics were applied where appropriate. Group comparisons were made based on the independent samples $t$ test, Mann-Whitney $U$ test, one-way ANOVA and Kruskal-Wallis ANOVA tests. If significant differences were found, post hoc comparisons were performed using the least significant difference (LSD) procedure or Mann-Whitney test (with Bonferroni adjustment). To investigate the relationship between variables, the Spearman correlation was used. The differences were considered statistically significant when $P$ values were less than 0.05 .

\section{Results}

Demographic and Clinical Data. The IGE patients and the controls were homologous with respect to age (15.5 years [SD, 1.2] and 15.5 years [SD, 1.1]), gender (boys/girls, 24/35 and 23/36), and duration of schooling (9.4 years [SD, 1.3] and 9.0 years [SD, 1.5]). The mean age at the onset of epilepsy in the IGE groups was 13.6 (SD, 2.6) years. The mean duration of active epilepsy was 14.1 months (median, 7 months; interquartile range, 22.5). Clinical data of the IGE group are presented in Table 1.

Within the past 3 months, 41 patients (69.5\%) had at least one GTCS; the median frequency of GTCS during that period was 1.0 ( $\min , 0 ; \max , 9$ ). There was no difference between the new-onset and the established IGE groups with regard to gender and schooling years, although patients with newonset IGE were younger than their counterparts in the established IGE group: 15.2 years $(S D, 1.2)$ and 15.8 years $(\mathrm{SD}, 1.1)$ respectively $(P=0.032)$. In the established IGE group, the majority of subjects received monotherapy: $20(74.1 \%)$ were treated with valproic acid, $4(14.8 \%)$ with lamotrigine, and 3 patients $(11.1 \%)$ were administered both drugs.

Generalized paroxysmal discharges on background EEG were recorded in a larger proportion of patients in the new-onset IGE group compared with the established epilepsy group: 15 of the 30 patients $(46.9 \%)$ and 5 of the 29 patients $(18.5 \%)$, respectively $(P=0.029)$. However, the presence of discharges
Table 1. Clinical Data of Patients With Idiopathic Generalized Epilepsy

\begin{tabular}{lr}
\hline \multicolumn{1}{c}{ Variable } & $\begin{array}{r}\text { Patients, } \\
\text { No. (\%) }\end{array}$ \\
\hline Type of seizures & $30(50.8)$ \\
GTCS only & $5(8.5)$ \\
GTCS and myoclonic jerks (with/without absences) & $24(40.7)$ \\
Myoclonic jerks without GTCS & $30(50.8)$ \\
\hline IGE syndrome & $29(42.2)$ \\
IGE with GTCS-only & $16(55.2)$ \\
\hline JME & $13(44.8)$ \\
Active myoclonias & $32(54.2)$ \\
Inactive myoclonias & $27(45.8)$ \\
\hline Duration and treatment & $10(16.9)$ \\
New-onset IGE, untreated & $49(83.1)$ \\
Established IGE, treated with AEDs & \\
Seizure activity: & $20(33.9)$ \\
Remission > 3 months & $53(89.8)$ \\
No remission & Paroxysmal discharges in EEG: \\
Present on background EEG & Present on sleep EEG
\end{tabular}

GTCS, generalized tonic-clonic seizure; IGE, idiopathic generalized epilepsy; JME, juvenile myoclonic epilepsy; AEDs, antiepileptic drugs; EEG, electroencephalography.

on sleep EEG did not differ between these groups.

There were more newly diagnosed patients in the M (-) group than in the $\mathrm{M}(+)$ group (21 of 30 [70\%] and 11 of 29 [37.9\%] respectively, $P=0.019)$. The $M(-)$ and the $M(+)$ groups did not differ according to other demographic characteristics (age, sex) and clinical variables (remission for at least three months, the occurrence and the number of GTCSs over the past three months, time-span since the last GTCS, age at the onset of epilepsy, presence of paroxysmal discharges on EEG).

Evaluation of Executive Functions. The results of all the tests of executive functions obtained in the IGE group, with its further subdivision into the new-onset IGE and the established IGE subgroups and also into the $M(-)$ IGE and the $M(+)$ IGE subgroups, and the control group are summarized Table 2 .

The total IGE group scored worse than the control group in all the tests for executive functions although not all the differences were significant. The IGE group subjects generated fewer items in phonemic task $(P=0.008)$, semantic task $(P=0.001)$, and they compounded fewer figures during the Five-Point Test $(P=0.008)$ as compared to controls. The percentage of figure repetition did not differ between the groups. The performance time for the TMT Part A and Part B was longer in the IGE group ( $P=0.001$ and $P=0.018$, respectively). The time difference score of the Stroop Test was higher in the IGE group but did not reach statistical significance $(P=0.053)$, and the number of errors/autocorrections during the third task did not differ between the IGE and control groups.

None of the test scores differed between the 
Table 2. Results of Executive Functions Tests for Control and Idiopathic Generalized Epilepsy Groups

\begin{tabular}{|c|c|c|c|c|c|c|}
\hline \multirow[b]{2}{*}{ Test } & \multirow[b]{2}{*}{$\begin{array}{l}\text { Control Group } \\
\quad(\mathrm{n}=59)\end{array}$} & \multirow[b]{2}{*}{$\begin{array}{l}\text { IGE Group } \\
(\mathrm{n}=59)\end{array}$} & \multicolumn{2}{|c|}{$\begin{array}{l}\text { IGE Group According to } \\
\text { Duration }\end{array}$} & \multicolumn{2}{|c|}{$\begin{array}{l}\text { IGE Group According } \\
\text { to Syndrome }\end{array}$} \\
\hline & & & $\begin{array}{c}\text { New-Onset } \\
\text { IGE } \\
(\mathrm{n}=32)\end{array}$ & $\begin{array}{c}\text { Established } \\
\text { IGE } \\
(\mathrm{n}=27)\end{array}$ & $\begin{array}{l}\text { M (-) IGE } \\
(\mathrm{n}=30)\end{array}$ & $\begin{array}{l}\text { M (+) IGE } \\
(\mathrm{n}=29)\end{array}$ \\
\hline 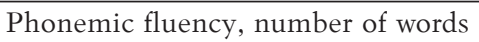 & 2 & 21.5 & $22.0(7.8)$ & $20.8(7.3)^{*}$ & $20.6(6.5)^{*}$ & .7) \\
\hline Semantic fluency, number of words & $48.3(8.6)$ & $41.8(9.1)^{* *}$ & $41.1(8.8)^{* *}$ & $42.7(9.5)^{*}$ & $40.8(9.4)^{* *}$ & $42.9(8.8)^{*}$ \\
\hline Five-Point Test, number of figures & $38.1(8.8)$ & $33.4(9.5)^{* *}$ & $34.1(9.4)$ & $32.6(9.7)^{*}$ & $32.6(9.8)^{* *}$ & $34.3(9.2)$ \\
\hline Five-Point Test, $\%$ of repetitions & $0.4(1.0)$ & $1.0(2.1)$ & $1.4(2.5)$ & $0.5(1.2)$ & $1.2(2.5)$ & $0.75(1.4)$ \\
\hline TMT Part A, seconds & $23.1(7.2)$ & $28.8(10.0)^{* *}$ & $28.9(10.1)^{* *}$ & $28.8(10.1)^{*}$ & $30.2(10.4)^{* *}$ & $27.4(9.6)$ \\
\hline TMT Part B, seconds & $51.6(16.1)$ & $61.0(21.2)^{*}$ & $59.5(15.7)$ & $62.7(26.5)$ & $55.8(13.3)$ & $66.3(26.3)^{* *}$ \\
\hline difference in seconds & $7.8(4.0)$ & $9.6(5.3)$ & $10.1(5.9)$ & $9.0(4.4)$ & $10.5(5.4)$ & $8.7(4.9)$ \\
\hline Stroop test errors, number & $0.8(0.9)$ & $1.1(1.3)$ & $1.5(1.5)$ & $0.7(0.8)$ & $1.2(1.3)$ & $1.1(1.4)$ \\
\hline
\end{tabular}

All values are mean (standard deviation). IGE, idiopathic generalized epilepsy; M (-), myoclonic jerks absent; $\mathrm{M}(+)$, myoclonic jerks present; TMT, Trail-Making Test.

${ }_{*}^{*} P<0.05 ; * * P \leqslant 0.01$ as compared with the control group.

new-onset IGE and the established IGE groups, and the differences among groups accounted only for the control group when the new-onset IGE, the established IGE, and the control groups were compared. The phonemic fluency of the established IGE group $(P=0.031)$ and the semantic fluency of both the new-onset IGE $(P=0.001)$ and the established IGE $(P=0.029)$ groups were worse as compared with the control group. Patients in the established IGE group scored worse than the control group in the Five-Point Test $(P=0.011)$. The number of errors in this test did not show any differences among the groups. The scores in the TMT Part A of both the new-onset IGE $(P=0.009)$ and the established IGE $(P=0.017)$ groups were worse when compared with the control group. The scores in the TMT Part B did not differ among the groups; the same refers to the Stroop Test results.

No difference in the results of any of the tests was found between the $\mathrm{M}(+)$ group and the $\mathrm{M}(-)$ group, and the group effects accounted only for the control group when M (-) IGE, M (+) IGE, and the control groups were compared. The scores in phonemic fluency of the M ( $)$ group $(P=0.016)$, and semantic fluency of both the M $(-)$ and the $M$ $(+)$ groups $(P=0.001$ and $P=0.023$ respectively) were worse than those of the control group. The Five-Point Test score of the M (-) group was lower as compared with the control group $(P=0.008)$. TMT Part A time scores in the M (-) group and Part $\mathrm{B}$ time scores in the $\mathrm{M}(+)$ group were higher as compared with the control group $(P=0.001$ and $P=0.002$, respectively). The Stroop Test score and the number of errors did not differ among the $M$ $(+)$, the $M(-)$, and the control groups. In the $M(+)$ group, the scores did not differ in cases with active and inactive myoclonic jerks.

In the IGE group, the age at epilepsy onset and the Five-Point Test score (the number of figures produced) showed a positive correlation $(r=0.38$, $P=0.003$ ), while the scores of other executive function tests showed no correlation with this variable.
Correlation was identified between the number of GTCSs within 3 months and the number of errors in the third task of the Stroop Test $(r=0.47$, $P=0.001)$; in addition, a negative correlation was identified between the latter score and the time since the occurrence of the last GTCS $(r=-0.3$, $P=0.027)$. The scores of other tests showed no correlation with either the number of GTCSs during the past 3 months or with the period after the last GTCS. Executive functions did not differ between the IGE patients in remission during the past 3 months and the ones without it, except for the error number in the Stroop Test, which was lower in the IGE group in remission $(1.3[\mathrm{SD}, 1.2]$ and 0.3 [SD, $0.4]$, respectively; $P=0.024)$. No correlation of executive functioning with the duration of active epilepsy was identified, also between the IGE groups with paroxysmal discharges on the background or sleep EEG and without them. There was no correlation between the age at the time of the study and the executive function test scores in both the IGE and control groups, and also any difference with regard to gender of the participants.

\section{Discussion}

The patients in the IGE group of adolescents with normal IQ (>70) and epilepsy of relatively short duration scored worse than the controls in most of the executive function tests used in this study: phonemic and semantic word fluency, figural fluency, visuomotor functioning and sequencing, except for the scores of the Stroop Test that measures the functions of selective attention and cognitive flexibility.

These results are consistent with previous studies that have reported impaired frontal functioning in patients with $\operatorname{IGE}(6,7,11,12,25,26)$, although the range of impaired functions reported has not been uniform, e.g., some studies showed the disturbance only in the tasks for verbal fluency and no difference from the control group in other tests (14, 21). These differences in results may have several explanations, one of them being the complexity of 
executive functioning and the possibility that not all the domains should be necessarily impaired. In addition, the performance of individual IGE patients may be not uniform, with some of them showing little or no deficit of the tested executive functions (6), the explanation under consideration being the genotypic and phenotypic heterogenicity of patients with IGE (27).

Since most of the studies evaluating executive functions have included patients with JME $(6,11-$ $14,21,25,26)$ and only few have investigated patients with other IGE syndromes (7, 22, 23, 28-30) (some of them having included patients with both partial and generalized idiopathic epilepsies), more data about the executive functions in IGE syndromes other than JME are necessary. Executive functions in the subgroups of IGE patients with GTCS only and those diagnosed with JME have been analyzed, and no difference between these two groups in any of the tests for executive functions used in this study has been found.

Analysis of the results within the IGE group with GTCS only revealed that these patients performed worse than controls in various domains of executive functioning: the phonemic and semantic verbal fluency, figural fluency, and TMT Part A test. Publications concerning the evaluation of the executive function in patients with IGE with GTCS only are scarce and results are variable. Henkin et al. did not find impaired word fluency in patients with GTCS compared to controls (7), while some other studies that included patients with GTCS found affected executive functions with no difference according to epilepsy syndrome (30) or seizure type (28). There are published data about the impairment of executive functioning in patients with absence epilepsy $(7,29)$. These findings imply that the impairment of executive functions may be present in other IGE syndromes.

Patients with JME performed worse just in two tests when compared with the control group: the tests of semantic word fluency and TMT Part B, the tasks that require organized thinking, attention, and cognitive flexibility. These findings contribute to the data of other studies, claiming that executive functions may be affected in patients with JME. However, our data show fewer impaired domains of executive functioning in the JME group as compared with some other studies $(6,11,12)$, although there are other reports about the lack of extensive deficit of executive function in patients with JME $(14,21)$. Taken these results together, we suggest that in some patients with JME of short duration, executive functioning may be only mildly affected, and subtle differences should be taken with caution in order to avoid overinterpretation.

According to the recognized diagnostic criteria, brain structural abnormalities in IGE should not be expected. However, the recent findings about the disorders of executive functions in JME have stimulated more sophisticated investigations on brain structure and functioning. Hutchinson et al. confirmed microstructural abnormalities in the white and gray matter of the frontal, parietal, temporal, occipital lobes and posterior corpus callosum in children with idiopathic new-onset epilepsy, although the study group included both generalized and partial epilepsy (31). Brain tissue abnormalities in the thalamic and frontal regions have been detected in children with recent IGE (32) and adults with JME (33); patients with GTCS only had a reduced gray matter fraction in multiple regions of the cortex including the frontal zone (34). Some other investigators, however, have not confirmed these findings in the thalamic (35) or frontal regions (14). Moeller et al. in their study of 6 children with IGE (only one of them being a JME case) by combined EEG-fMRI investigation have reported that a generalized epileptic discharge on EEG was preceded by a sequence of neuronal events in the thalamo-cortical (frontoparietal)-striatal network (36), thus supplementing the data on localization-related structural characteristic features of the brain in IGE. The results of our study support the findings of previous reports on neuropsychology and neuroimaging that the disorders of executive function are characteristic of IGE. Our data have added some evidence that IGE presenting with myoclonias may not demonstrate any closer relationship to the disturbance of executive functions as compared with syndromes of adolescent IGE without myoclonias. As most of the studies have investigated JME, which is the bestdelineated IGE syndrome, further explorations of the brain functioning in other IGE syndromes may be relevant in the future.

The question under discussion is when the impairment of executive functioning and volumetric brain changes in patients with IGE take place. Is this related to the duration of epilepsy, seizure frequency, or treatment? The impairment of cognition including executive functions in patients with recent idiopathic epilepsy has been detected $(23,30)$. Pulsipher et al. have also found executive dysfunction and volumetric changes in adolescents with recent epilepsy, although all their patients received antiepileptic treatment (25). In our series with relatively recent epilepsy, the results of executive functioning did not differ between the newly diagnosed untreated and established IGE patients receiving AED, and both the groups scored worse than the controls in a range of tests evaluating executive functions. The analysis of the possible correlation of executive functioning with seizure frequency, the number of recent GTCSs, or the time interval from the last GCTS showed that only the number of errors in the Stroop Test was related to the abovementioned factors. It might implicate that recent active seizures are associated with a higher level of distractibility, 
although the variability of the results in this test and the small number of patients that made errors attenuate the interpretation of this correlation. No other results showed relationships to any of the evaluated clinical characteristics, except the young age at seizure onset, which demonstrated a single positive correlation with the scores for figural fluency. We refrain from further speculations on the latter isolated finding since no other significant correlations of this variable were found.

The results of our study support the hypothesis that executive dysfunction (and possibly the volumetric brain changes) is more related to certain epilepsy syndromes rather than to the duration and the severity of epilepsy. These presumptions are supported by the fact that idiopathic focal epilepsy of the same duration has been related neither to the executive dysfunction nor to the structural or functional changes in the frontal regions $(25,37)$. The above mentioned volumetric and structural evaluations support the hypothesis that cognitive dysfunction and associated structural and/or functional changes, especially in adolescents with recent epilepsy, possibly have a genetic predisposition (32). The impact of seizure frequency, long-lasting epilepsy course, and medications remains unclear because of interaction of these factors.

\section{Conclusions}

Risk of the impairment of executive functioning exists in adolescents with idiopathic generalized epilepsy despite of short duration and benign course of epilepsy. Patients in our study demonstrated impaired verbal and figural fluency, sequencing and visual search, while cognitive flexibility and susceptibility to interference were comparable with age-matched controls. Executive functioning in this young patient population was not related to the duration or the activity of epilepsy, the exposure to antiepileptic drugs, or the presence or absence of myoclonias. We conclude that executive dysfunction may be present in other idiopathic generalized epilepsy syndromes of adolescence, not being the exceptional feature of juvenile myoclonic epilepsy. As the impairment of executive functions is very important in adolescents with epilepsy for its impact on the learning process, we suggest a neuropsychological evaluation in patients with idiopathic generalized epilepsy early in the course of the disease in order to provide adequate intervention when necessary.

\section{Acknowledgments}

The authors gratefully acknowledge the cooperation of all patients and families participating in this study. In addition, the authors are thankful to all their colleagues, especially Prof. Nerija VaičienèMagistris for referring patients for this investigation as well as clinical psychologist Ilona Laukienè for the consultations regarding the methodology of this study. This study was supported by the grant from the State Studies Foundation, Lithuania.

\section{Statement of Conflict of Interest}

The authors state no conflict of interest.

\title{
Paauglių, sergančių idiopatine generalizuota epilepsija, pažinimo funkcijos
}

\author{
Giedrẻ Gelžiniené ${ }^{1}$, Giedrẻ Jurkevičiené $\dot{e}^{1}$, Vitalija Marmiené2, \\ Virginija Adomaitien $\dot{e}^{2}$, Milda Endziniené $\dot{e}^{1}$ \\ ${ }^{1}$ Lietuvos sveikatos mokslu universiteto Medicinos akademijos Neurologijos klinika, \\ ${ }^{2}$ Lietuvos sveikatos moksly universiteto Medicinos akademijos Psichiatrijos klinika
}

Raktažodžiai: idiopatine generalizuota epilepsija, aukštosios (frontalinės) pažinimo funkcijos, mioklonijos, generalizuoti toniniai-kloniniai traukuliai.

Santrauka. Pastaraisiais metais pasirodè duomenų apie aukštųjų (frontalinių) pažinimo funkcijų sutrikimus pacientams, sergantiems jaunuolių mioklonijų epilepsija (JME), tačiau kiti idiopatinės generalizuotos epilepsijos (IGE) sindromai, ypač paauglystės laikotarpio, tyrinėti mažai.

Tyrimo tikslas. Ištirti neilgai IGE sergančių paauglių aukštąsias (frontalines) pažinimo funkcijas ir galimus rizikos veiksnius.

Tyrimo medžiaga ir metodai. Naudodami pažinimo funkcijų testus (neverbalinio laisvumo, skaičių ir raidžių sujungimo ir Stroop testai), ištyrėme aukštąsias (frontalines) pažinimo funkcijas 59 (14-17 metu amžiaus) pacientams, atitinkantiems IGE kriterijus, bei 59 atitinkamo amžiaus paaugliams, niekada nesirgusiems epilepsija.

Rezultatai. Daugumos IGE sergančiųju aukštųju (frontalinių) pažinimo funkcijų tyrimo rezultatai buvo blogesni nei kontrolinès grupès: foneminis $(p=0,008)$ ir semantinis $(p=0,001)$ žodžių laisvumas, neverbalinis laisvumas $(p=0,008)$, skaičiu sujungimo ir alternuojančio skaičiu ir raidžių sujungimo testai (atitinkamai $-p=0,001$ ir $p=0,018$ ). Aukštosios (frontalinès) pažinimo funkcijos nesiskyrè tarp naujai susirgusių negydomų bei sergančių ir gydomų pacientų, taip pat tarp patiriančių mioklonijas ir jų nepatiriančių. Nerasta aukštųjų (frontalinių) pažinimo funkcijų sutrikimų ryšio su tiriamųjų lytimi, amžiumi, epilepsijos trukme, aktyvumu, vaistų vartojimu bei epilepsiniais pokyčiais elektroencefalogramoje. 
Išvados. Aukštųių (frontalinių) pažinimo funkcijų sutrikimai nustatyti paaugliams, sergantiems JME bei kitais IGE sindromais, pasireiškiantiems generalizuotais toniniais-kloniniais traukuliais be mioklonijų, nepaisant neilgos epilepsijos trukmès bei gerybinès jos eigos.

\section{References}

1. Commission on classification and terminology of the International League Against Epilepsy. Proposal for revised classification of epilepsies and epileptic syndromes. Epilepsia 1989;30:389-99.

2. Berg AT, Berkovic SF, Brodie MJ, Buchhalter J, Cross JH, van Emde Boas W, et al. Revised terminology and concepts for organization of seizures and epilepsies: report of the ILAE commission on classification and terminology, 2005-2009. Epilepsia 2010;51:676-85.

3. Cutting S, Lauchheimer A, Barr W, Devinsky O. Adult-onset idiopathic generalized epilepsy: clinical and behavioral features. Epilepsia 2001;42:1395-8.

4. Bailet LL, Turk WR. The impact of childhood epilepsy on neurocognitive and behavioral performance: a prospective longitudinal study. Epilepsia 2000;41:426-31.

5. Pavone $\mathrm{P}$, Bianchini R, Trifiletti RR, Incorpora G, Pavone A, Parano E. Neuropsychological assessment in children with absence epilepsy. Neurology 2001;56:1047-51.

6. Devinsky O, Gershengorn J, Brown E, Perrine K, Vazquez B, Luciano D. Frontal functions in juvenile myoclonic epilepsy. Neuropsychiatry Neuropsychol Behav Neurol 1997; 10:243-6.

7. Henkin Y, Sadeh M, Kivity S, Shabtai E, Kishon-Rabin L, Gadoth N. Cognitive function in idiopathic generalized epilepsy of childhood. Dev Med Child Neurol 2005;47:126-32.

8. Bhise V, Burack GD, Mandelbaum DE. Baseline cognition, behavior, and motor skills in children with new-onset, idiopathic epilepsy. Dev Med Child Neurol 2009;52:22-6.

9. Oostrom KJ, van Teeseling H, Smeets-Schouten A, Peters AC, Jennekens-Schinkel A; Dutch Study of Epilepsy in Childhood (DuSECh). Three to four years after diagnosis: cognition and behavior in children with 'epilepsy only'. A prospective, controlled study. Brain 2005;128:1546-55.

10. Hommet C, Sauerwein HC, De Toffol B, Lassonde M. Idiopathic epileptic syndromes and cognition. Neurosci Biobehav Rev 2006;30:85-96.

11. Sonmez F, Atakli D, Sari H, Atay T, Arpaci B. Cognitive function in juvenile myoclonic epilepsy. Epilepsy Behav 2004;5:329-36.

12. Piazzini A, Turner K, Vignoli A, Canger R, Canevini MP. Frontal cognitive dysfunction in juvenile myoclonic epilepsy. Epilepsia 2008;49:657-62.

13. Iqbal N, Caswell HL, Hare DJ, Pilkington O, Mercer S, Duncan S. Neuropsychological profiles of patients with juvenile myoclonic epilepsy and their siblings: a preliminary controlled experimental video-EEG case series. Epilepsy Behav 2009;14:516-21.

14. Roebling R, Scheerer N, Uttner I, Gruber O, Kraft E, Lerche H. Evaluation of cognition, structural, and functional MRI in juvenile myoclonic epilepsy. Epilepsia 2009;50:2456-65.

15. Stuss DT, Alexander MP. Executive functions and the frontal lobes: a conceptual view. Psychol Res 2000;63:289-98.

16. Strauss E, Sherman EM, Spreen O. Executive functions. Attention. In: A compendium of neuropsychological tests: administration, norms, and commentary. Oxford: Oxford University Press; 2006. p. 401-678.

17. Woermann FG, Free SL, Koepp MJ, Sisodiya SM, Duncan S. Abnormal cerebral structure in juvenile myoclonic epilepsy demonstrated with voxel-based analysis of MRI. Brain 1999;122:2101-7.

18. Savic I, Lekvall A, Greitz D, Helms G. MR spectroscopy shows reduced frontal lobe concentrations of $\mathrm{N}$-acetyl aspartate in patients with juvenile myoclonic epilepsy. Epilepsia 2000;41:290-6.

19. Savic I, Österman Y, Helms G. MRS shows syndrome differentiated metabolite changes in human-generalized epi- lepsies. Neuroimage 2004;21:163-72.

20. Betting LE, Mory SB, Li LM, Lopes-Cendes I, Guerreiro MM, Guerreiro CA, et al. Voxel-based morphometry in patients with idiopathic generalized epilepsies. Neuroimage 2006;32:498-502.

21. Meador KJ. Brain function and anatomy in juvenile myoclonic epilepsy. Epilepsy Curr 2010;10:13-4.

22. Parrish J, Geary E, Jones J, Seth R, Hermann B, Seidenberg M. Executive functioning in childhood epilepsy: parentreport and cognitive assessment. Dev Med Child Neurol 2007;49:412-6.

23. Hermann BP, Jones JE, Sheth R, Koehn M, Becker T, Fine J, et al. Growing up with epilepsy: a two-year investigation of cognitive development in children with new onset epilepsy. Epilepsia 2008;49:1847-58.

24. Treitz FH, Daum I, Faustmann PM, Haase CG. Executive deficits in generalized and extrafrontal partial epilepsy: long versus short seizure-free periods. Epilepsy Behav 2009; 14:66-70.

25. Pulsipher DT, Seidenberg M, Guidotti L, Tuchscherer VN, Morton I, Sheth RD, et al. Thalamofrontal circuitry and executive dysfunction in recent-onset juvenile myoclonic epilepsy. Epilepsia 2009;50:1210-9.

26. O'Muircheartaigh J, Vollmar C, Barker GJ, Kumari V, Symms MR, Thompson $\mathrm{P}$, et al. Focal structural changes and cognitive dysfunction in juvenile myoclonic epilepsy. Neurology 2011;76:34-40.

27. Mefford HC, Muhle H, Ostertag P, von Spiczak S, Buysse $\mathrm{K}$, Baker $\mathrm{C}$, et al. Genome-wide copy number variation in epilepsy: novel susceptibility loci in idiopathic generalized and focal epilepsies. PLoS Genet 2010:6(5):e1000962.

28. Høie B, Mykletun A, Waaler P, Skeidsvoll H, Sommerfelt K. Executive functions and seizure-related factors in children with epilepsy in Western Norway. Dev Med Child Neurol 2006;48:519-25.

29. Conant LL, Wilfong A, Inglese C, Schwarte A. Dysfunction of executive and related processes in childhood absence epilepsy. Epilpsy Behav 2010;18:414-23.

30. Taylor J, Kolamunnage-Dona R, Marson AG, Smith PE, Aldenkamp AP, Baker GA. Patients with epilepsy: cognitively compromised before the start of antiepileptic drug treatment? Epilepsia 2010;51:48-56.

31. Hutchinson E, Pulsipher D, Dabbs K, Gutierrez AM, Sheth $\mathrm{R}$, Jones J, et al. Children with new-onset epilepsy exhibit diffusion abnormalities in cerebral white matter in the absence of volumetric differences. Epilepsy Res 2010;88:208-14.

32. Pulsipher D, Dabbs K, Tuchsherer V, Sheth R, Koehn M, Hermann B, et al. Thalamofrontal neurodevelopment in new-onset pediatric idiopathic generalized epilepsy. Neurology 2011;76:28-33.

33. de Araújo Filho GM, Jackowski AP, Lin K, Guaranha MS, Guilhoto LM, da Silva HH, et al. Personality traits related to juvenile myoclonic epilepsy: MRI reveals prefrontal abnormalities through a voxel-based morphometry study. Epilepsy Behav 2009;15:202-7.

34. Ciumas C, Savic I. Structural changes in patients with primary generalized tonic and clonic seizures. Neurology 2006;67:683-6.

35. Seeck M, Dreifuss S, Lantz G, Jallon P, Foletti G, Despland $P$, et al. Subcortical nuclei volumetry in idiopathic generalized epilepsy. Epilepsia 2005;46:1642-5.

36. Moeller F, Siebner HR, Wolff S, Muhle H, Boor R, Granert $\mathrm{O}$, et al. Changes in activity of striato-thalamo-cortical network precede generalized spike wave discharges. Neuroimage 2008;39:1839-49.

37. Boxerman JL, Hawash K, Bali B, Clarke T, Rogg J, Pal DK. Is Rolandic epilepsy associated with abnormal findings on cranial MRI? Epilepsy Res 2007;75:180-5. 